\title{
Redox processes acidify and decarboxylate steam-pretreated lignocellulosic biomass and are modulated by LPMO and catalase
}

\author{
Ausra Peciulyte ${ }^{1}$, Louise Samuelsson ${ }^{1}$, Lisbeth Olsson ${ }^{1}$, K. C. McFarland ${ }^{2}$, Jesper Frickmann ${ }^{3}$, Lars Østergård ${ }^{4}$,
} Rune Halvorsen ${ }^{4}$, Brian R. Scott ${ }^{2}$ and Katja S. Johansen ${ }^{1,4,5^{*}}$ (1)

\begin{abstract}
Background: The bioconversion of lignocellulosic feedstocks to ethanol is being commercialised, but further process development is required to improve their economic feasibility. Efficient saccharification of lignocellulose to fermentable sugars requires oxidative cleavage of glycosidic linkages by lytic polysaccharide monooxygenases (LPMOS). However, a proper understanding of the catalytic mechanism of this enzyme class and the interaction with other redox processes associated with the saccharification of lignocellulose is still lacking. The in-use stability of LPMO-containing enzyme cocktails is increased by the addition of catalase implying that hydrogen peroxide $\left(\mathrm{H}_{2} \mathrm{O}_{2}\right)$ is generated in the slurry during incubation. Therefore, we sought to characterize the effects of enzymatic and abiotic sources of $\mathrm{H}_{2} \mathrm{O}_{2}$ on lignocellulose hydrolysis to identify parameters that could improve this process. Moreover, we studied the abiotic redox reactions of steam-pretreated wheat straw as a function of temperature and dry-matter (DM) content.
\end{abstract}

Results: Abiotic reactions in pretreated wheat straw consume oxygen, release carbon dioxide $\left(\mathrm{CO}_{2}\right)$ to the slurry, and decrease the $\mathrm{pH}$. The magnitude of these reactions increased with temperature and with DM content. The presence of $\mathrm{LPMO}$ during saccharification reduced the amount of $\mathrm{CO}_{2}$ liberated, while the effect on $\mathrm{pH}$ was insignificant. Catalase led to increased decarboxylation through an unknown mechanism. Both in situ-generated and added $\mathrm{H}_{2} \mathrm{O}_{2}$ caused a decrease in $\mathrm{pH}$.

Conclusions: Abiotic redox processes similar to those that occur in natural water-logged environments also affect the saccharification of pretreated lignocellulose. Heating of the lignocellulosic material and adjustment of pH trigger rapid oxygen consumption and acidification of the slurry. In industrial settings, it will be of utmost importance to control these processes. LPMOs interact with the surrounding redox compounds and redirect abiotic electron flow from decarboxylating reactions to fuel the oxidative cleavage of glycosidic bonds in cellulose.

Keywords: Hydrogen peroxide, pH/proton activity, Biorefinery, Decarboxylation, Enzymes, Wheat straw

\footnotetext{
*Correspondence: skatja@chalmers.se

${ }^{1}$ Division of Industrial Biotechnology, Department of Biology and Biological Engineering, Chalmers University of Technology, Kemivägen 10, 41296 Gothenburg, Sweden

Full list of author information is available at the end of the article
} 


\section{Background}

Decomposition of plant material in nature is driven primarily by the action of microbial enzymes capable of deconstructing the complex structure of the plant cell wall. In addition to enzymes, abiotic (non-enzymatic) reactions driven by redox processes also play an important role [1]. An important contribution to abiotic decomposition of organic matter involves reactive oxidants produced by $\mathrm{Fe}(\mathrm{II})$ oxidation. This pathway is likely one of the mechanisms through which organic compounds are oxidized under acidic conditions [2]. Moreover, dissolved organic matter has been shown to be an integral component in biogeochemical electron transfer reactions due to its ability to facilitate redox reactions [3].

Agricultural and forestry residues are the primary lignocellulosic feedstocks being used to produce ethanol in commercial facilities. The biomass is usually subjected to chemical and/or physical pretreatment, followed by enzymatic hydrolysis and ethanol fermentation. Interestingly, the industrial saccharification of lignocellulose takes place under conditions that resemble those in the natural environment in peat bogs. This ecological niche is characterised by fluctuating concentrations of oxygen in the upper strata of the bog. A few centimetres below the secondary water table, the oxidative process consumes the dissolved oxygen at a rate higher than the passive influx from the air.

Industrial saccharification of lignocellulose relies on highly optimised enzyme cocktails for the efficient release of monosaccharides from the pretreated feedstock. Lytic polysaccharide monooxygenases (LPMOs), a group of enzymes discovered in more recent years [4], are often included in such enzyme cocktails and are particularly important drivers of cellulose hydrolysis performance. LPMOs are $\mathrm{Cu}$-containing enzymes that require oxygen and a source of electrons to cleave glycosidic bonds [5, 6]. Importantly, certain LPMOs initiate cellulose degradation by cleaving internal $\beta 1,4$-glycosidic bonds without prior hydration (de-crystallisation) of individual cellulose chains. In doing so, LPMOs create access points for processive exo-cellulases [7]. Therefore, to achieve efficient saccharification, it is important that oxygen and appropriate electron donors are present [8-10]. Recent work suggests that activated oxygen in the form of $\mathrm{H}_{2} \mathrm{O}_{2}$ may serve as the co-substrate for LPMO catalytic cleavage of polysaccharides [11-13] rather than or in addition to dioxygen. This scheme is discussed in the context of the results generated in this paper in "Discussion".

Lignocellulose is rich in phenolic compounds as industrial pretreatments, such as acid and neutral steam explosion, only partially disrupt and solubilize the lignin fraction. These phenolic compounds serve as electron donors for LPMO reactivity during saccharification, and in many cases, no exogenous reducing agent is required $[6,14,15]$. The LPMO-activating properties of many individual phenolic compounds have been tested [10, 1618]. The redox potential of the electron donors is critical for the LPMO reactivity $[6,17]$.

The oxygen content of pretreated lignocellulosic material used in industrial saccharification has not been described systematically, but will be highly processand configuration dependent. However, the interaction between the enzymatic and the abiotic oxygen-consuming redox reactions is complex and largely unexplored. This is illustrated in Fig. 1.

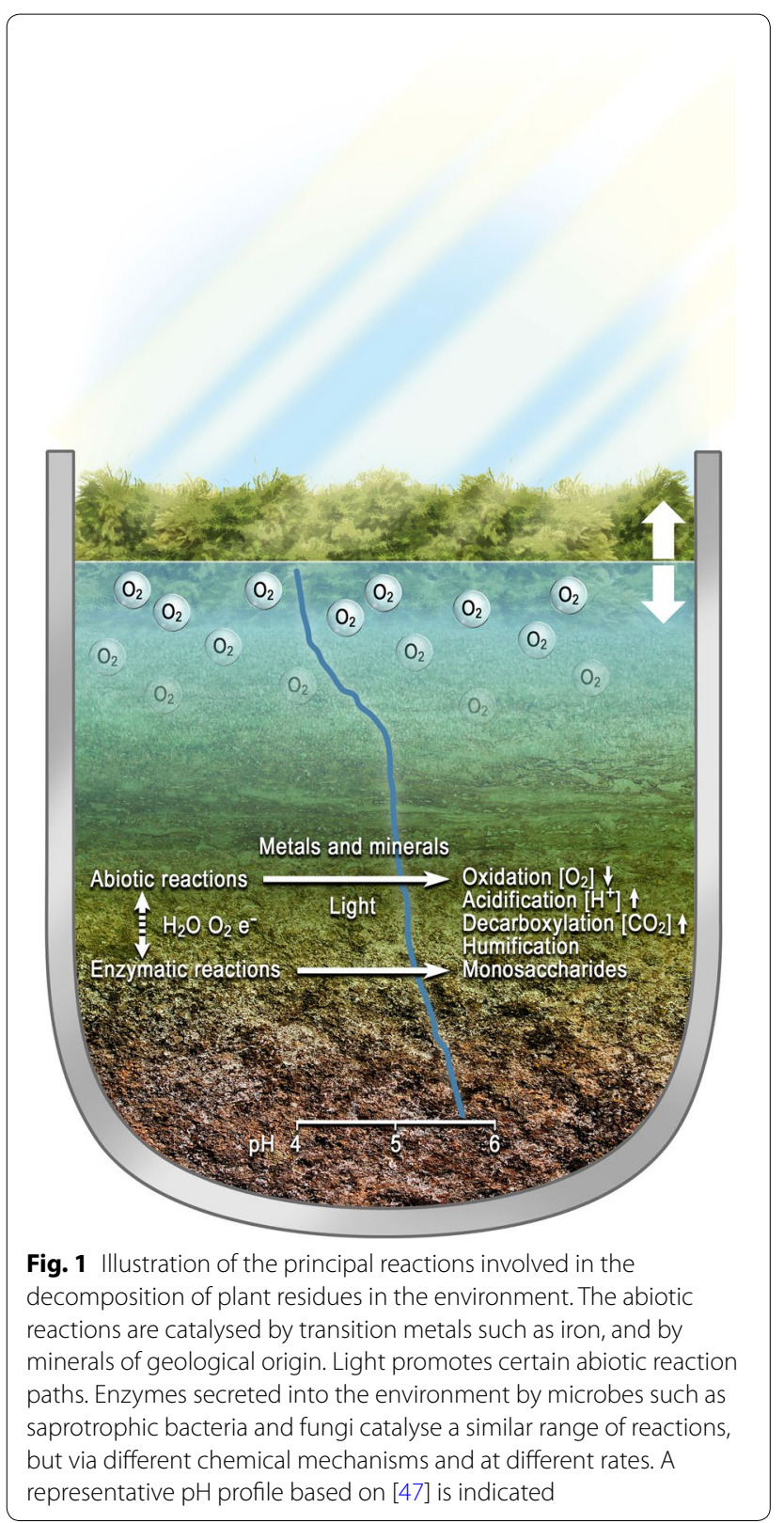


In nature, both the microbial decomposition processes involving extracellular enzymes and abiotic reactions are inhibited by acidic and reduced-oxygen conditions. The dissolved oxygen level is also an important parameter for optimal enzymatic hydrolysis of lignocellulose. A low level of dissolved oxygen ( $2 \%$ saturation from the air) is reportedly advantageous for the saccharification of pretreated wheat straw when compared to further reduced-oxygen conditions achieved by purging the reaction with nitrogen gas [18]. However, oxidative inactivation of commercial cellulase mixtures is a significant factor influencing the overall saccharification efficiency under ambient oxygen conditions, and the addition of catalase has been shown to reduce the inactivation rate of cellulase mixtures [9].

In stirred-tank bioreactors, such as those used in industry and in pilot-scale laboratories, the $\mathrm{pH}$ is automatically adjusted to a value determined by the optimum $\mathrm{pH}$ for the enzyme cocktail. Prior to this study, the amount of base titrant required during the saccharification of lignocellulose was highly variable and dependent on the concentration of dissolved oxygen, as described below. Surprisingly, the addition of catalase dramatically reduced the requirement of base titrant at $2 \%$ oxygen saturation of the slurry [19]. It has been assumed that enzymatic hydrolysis reactions by acetyl xylan esterases present in the enzymatic cocktail caused the lowering of the $\mathrm{pH}$ as a result of acetic acid released from hemicelluloses [20]. However, this hypothesis does not explain the oxygen-dependent nature of the acidification of lignocellulosic material.

The aim of this study was to gain new insights into the abiotic and enzymatic redox reactions taking place during the saccharification of pretreated lignocellulose and their dependence on the reaction conditions. We investigated the effect of the redox enzymes, LPMO and catalase, on these abiotic oxidative processes and vice versa. The composition of headspace gas samples was determined, and the change in $\mathrm{pH}$ in the saccharification slurry was monitored. Moreover, the effect of $\mathrm{H}_{2} \mathrm{O}_{2}$ delivery to the saccharification mixture by means of aldose oxidase or by adding $\mathrm{H}_{2} \mathrm{O}_{2}$ was studied. The aldose oxidase from Microdochium nivale ( $\mathrm{MnAOx})$ [21], an AA7 enzyme that can oxidize several mono-, oligo-, and polymeric saccharides and in the process transfers electrons to molecular oxygen, was used for generating $\mathrm{H}_{2} \mathrm{O}_{2}$ in situ.

\section{Results}

Requirement of base titrant in stirred-tank reactor trials As indicated above, including a dissolved oxygen level of $2 \%$ saturation (with full saturation with the air being $100 \%$ ) was advantageous for the saccharification of steam-pretreated wheat straw due to the oxygen-dependent activity of the LPMO included in the enzyme cocktail [19]. However, this level of dissolved oxygen also led to almost a doubling of the base titrant required to maintain the $\mathrm{pH}$ at the set value of 5.0 during incubation (Table 1). The findings of this pilot study also demonstrated that the addition of catalase together with $2 \%$ oxygen saturation clearly reduced the amount of titrant required, and substantially improved the sugar yield after 5 days of incubation.

It was clear from the above data that there is no direct coupling between the amount of titrant required and the sugar yield. This observation was substantiated in stirredtank saccharification experiments with DM contents of $12,14,16$, and $18 \%$ (Additional file 1: Table S1A), and incubation temperatures of $46,48,50$, and $52{ }^{\circ} \mathrm{C}$ (Additional file 1: Table S1B).

\section{The abiotic component of $\mathrm{pH}$ decrease}

To study the factors underlying the decrease in $\mathrm{pH}$ (increase in $\mathrm{H}^{+}$activity) of pretreated lignocellulose in greater detail, steam-pretreated wheat straw slurry was first incubated at four different DM concentrations $(1,2$, 5 , and $10 \%(\mathrm{wt} / \mathrm{wt}))$ and four different temperatures (40, 45,50 , and $60{ }^{\circ} \mathrm{C}$ ), for $24 \mathrm{~h}$ in sealed serum bottles without the addition of any enzymes. Prior to the incubation, the pretreated wheat straw slurry had a $\mathrm{pH}$ at room temperature of 3.6. This increased slightly upon dilution of the slurry with tap water to DM contents of $1,2,5$, and 10\% (Additional file 1: Figure S1A). The requirement of $\mathrm{KOH}$ per gram of $\mathrm{DM}$ to adjust $\mathrm{pH}$ to 5.3 increased as $\mathrm{DM}$ concentration increased (Additional file 1: Figure $\mathrm{S} 1 \mathrm{~B})$. The $\mathrm{pH}$ of the slurry as a function of DM and temperature after incubation is shown in Fig. 2a, b.

A strong correlation was observed between the decrease in $\mathrm{pH}$ and increasing incubation temperature. The effect of DM content on the $\mathrm{pH}$ of the slurry is clear at lower DM concentrations of 1 and $2 \%$. At 5 and $10 \% \mathrm{DM}$, the differences in $\mathrm{pH}$ are small. Acidification of the slurry at 5 and 10\% DM may be limited by oxygen or redox-scavenging effects of lignin [22] and sugars $[23,24]$. Nonetheless, it is evident that in the cases

Table 1 Data on the combined effect on sugar release and titrant requirement for a controlled level of oxygen saturation and the addition of catalase during saccharification of steam-pretreated wheat straw at $20 \%$ DM content. Reproduced with permission from [16]

\begin{tabular}{|c|c|c|c|c|c|}
\hline \multirow[b]{2}{*}{ Incubation time } & \multicolumn{2}{|c|}{ Glucose (g/L) } & \multicolumn{2}{|c|}{ Xylose (g/L) } & \multirow{2}{*}{$\begin{array}{l}25 \% \mathrm{NaOH} \\
\text { titration }(\mathrm{mL}) \\
5 \text { days }\end{array}$} \\
\hline & 3 days & 5 days & 3 days & 5 days & \\
\hline $\mathrm{N}_{2}$-flushed & 45.2 & 49.5 & 23.3 & 23.6 & 4.9 \\
\hline $2 \% \mathrm{O}_{2}$ & 61.4 & 63.3 & 24.9 & 25.1 & 9.6 \\
\hline $2 \% \mathrm{O}_{2}+$ catalase & 60.2 & 67.8 & 24.9 & 26.3 & 5.7 \\
\hline
\end{tabular}



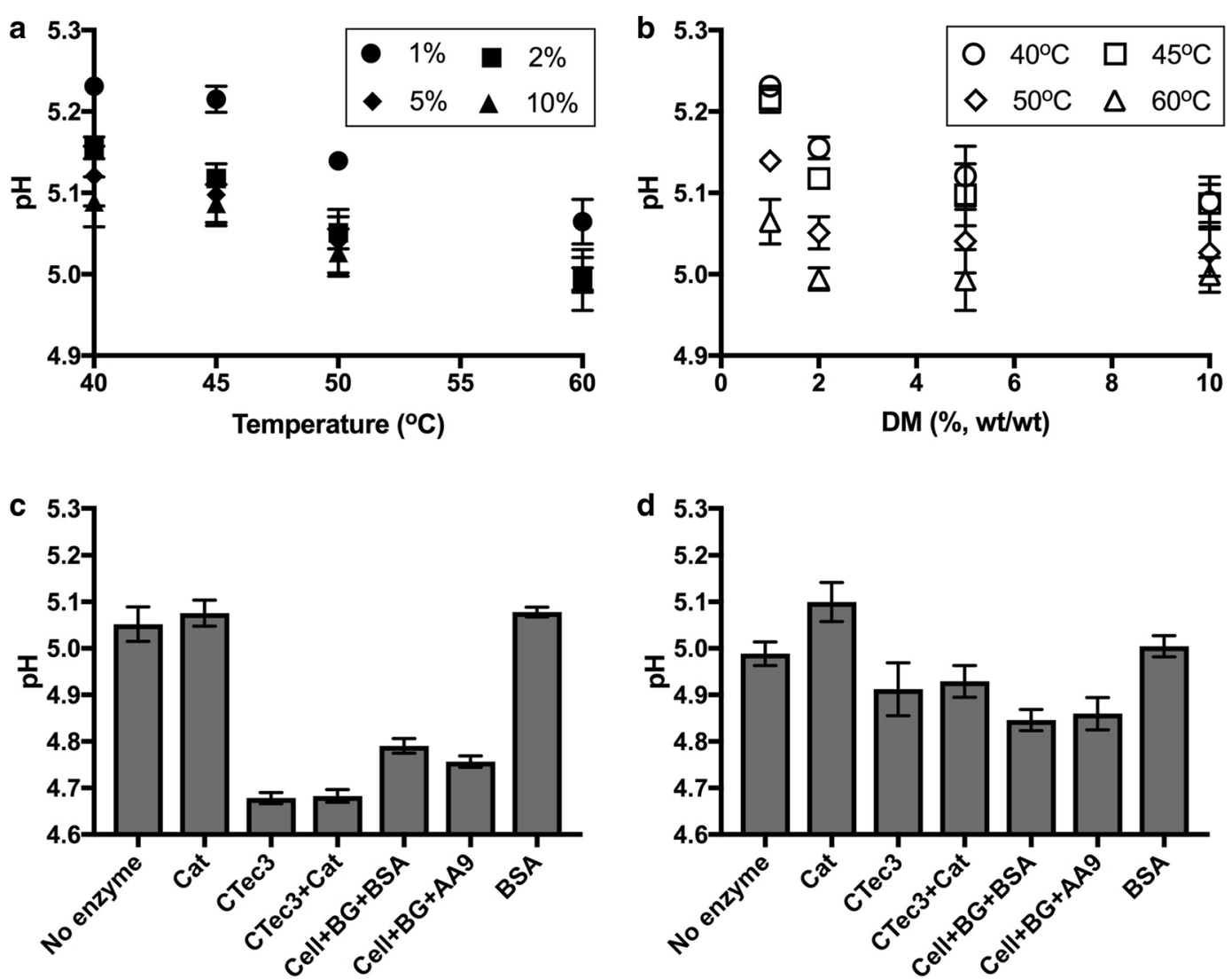

Fig. 2 Change in $\mathrm{pH}$ of pretreated wheat straw slurry during $24 \mathrm{~h}$ of incubation. $\mathbf{a}$ Effect of incubation temperature and $\mathbf{b}$ effect of DM content in the absence of enzymes. Steam-pretreated wheat straw was diluted to DM contents of 1, 2, 5, or 10\% (wt/wt), the pH was adjusted to 5.3, and the samples incubated at $40,45,50$, or $60^{\circ} \mathrm{C}$. $\mathbf{c}$, $\mathbf{d}$ Show the effect of enzyme addition to pretreated wheat straw slurry at $10 \%$ DM incubated at $50^{\circ} \mathrm{C}$. The data shown in (d) are the result of re-adjusting the $\mathrm{pH}$ to 5.0-5.1 and continuing incubation for an additional $24 \mathrm{~h}$. The values given are the average of 3-12 replicates, and the error bars represent the standard deviation. No enzyme no addition of enzymes, $\mathrm{Cat}$ catalase; $\mathrm{CTec}$ : Cellic ${ }^{\circledR}$ CTec3; Cell: Celluclast 1.5L; BG: $\beta$-glucosidase; BSA: bovine serum albumin; AA9: TaAA9A

investigated, the $\mathrm{pH}$ of the slurry decreased during incubation without added enzymes in the presence of oxygen. For example, at $10 \% \mathrm{DM}$ content and $50{ }^{\circ} \mathrm{C}$, the $\mathrm{pH}$ decreased from 5.3 to 5.0 in 24 h due to abiotic reactions in the lignocellulosic slurry.

\section{The enzymatic component of acidification during saccharification}

To investigate whether LPMO and catalase activity affected the amount of base titrant required during saccharification, enzyme mixtures with and without supplemental AA9 from Thermoascus aurantiacus (TaAA9) were used under ambient and reduced-oxygen conditions. Celluclast ${ }^{\circledR}$, which is a wild-type Trichoderma reesei whole-enzyme mixture, was used as an LPMO-poor cellulase cocktail. Mixtures were prepared containing $80 \%$ Celluclast $^{\circledR}$ (by protein mass) and $10 \% \beta$-glucosidase (BG) to ensure rapid and complete conversion of cellobiose to glucose, thereby avoiding product inhibition of the cellobiohydrolases and simplifying product quantification. The remaining $10 \%$ of the mix consisted of either TaAA9 or inert protein in the form of BSA. Furthermore, the effects of an LPMO-rich cellulose cocktail Cellic ${ }^{\circledR}$ CTec3 (referred to hereafter as CTec3) and Thermoascus aurantiacus catalase were evaluated. All slurry samples had acidified after $24 \mathrm{~h}$ (Fig. 2c) and after $\mathrm{pH}$ adjustment and further $24 \mathrm{~h}$ of incubation (Fig. 2d). Cellulase cocktails had a strong acidifying effect on $\mathrm{pH}$, whereas TaAA9 had no clear effect. Catalase addition to the slurry had only a minor effect on $\mathrm{pH}$ under the conditions tested here.

\section{Can acetic acid release explain the acidification?}

The acetic acid concentration in wheat straw samples with and without enzyme treatment was quantified to investigate whether acetic acid release could explain the observed acidification. The samples with the $\mathrm{pH}$ ranging from 3.6 to 5.3 were analysed by HPLC. In this $\mathrm{pH}$ range, 
the samples contained a mixture of dissociated form (acetate) and undissociated form of acetic acid. During the analysis, the $\mathrm{pH}$ of the eluent was 2 , and at this $\mathrm{pH}$, almost $100 \%$ of acetic acid molecules exist in undissociated form. The $10 \%$ slurry contained about $1.4 \mathrm{~g} / \mathrm{L}$ acetic acid, and this concentration remained almost constant throughout $172 \mathrm{~h}$ of incubation at $50^{\circ} \mathrm{C}$ in the absence of enzymes (Fig. 3a). This is in contrast to the change in $\mathrm{pH}$ from 5.3 to 5.0 during $24 \mathrm{~h}$ of incubation (Fig. 2c). The addition of CTec3 with or without catalase resulted in a gradual increase in acetic acid concentration. The release of acetic acid was initially rapid, but levelled off resulting in approximately $2.6 \mathrm{~g} / \mathrm{L}$ acetic acid at both high and low $\mathrm{CTec} 3$ concentrations. The presence of catalase had no effect on acetic acid concentration (Fig. 3a).

To further study the $\mathrm{pH}$-stabilising effect of catalase, pretreated wheat straw was adjusted to $\mathrm{pH} 5.3$ after dilution with tap water to 2 and 10\% DM (as before). Three doses of catalase $(0.08,0.13$, and $0.19 \mathrm{mg} / \mathrm{g} \mathrm{DM})$ were added. After $24 \mathrm{~h}$ of incubation, the slurry had acidified in all cases (Fig. 3b). In the absence of catalase, both 2 and $10 \%$ DM slurry samples acidified from $\mathrm{pH} 5.3$ to 5.0. The drop in $\mathrm{pH}$ was reduced in the presence of catalase, as the final $\mathrm{pH}$ was approximately 5.13 in the $2 \%$ DM samples and $\mathrm{pH} 5.08$ in the 10\% DM samples. For a correct comparison of $\mathrm{pH}$ values, all the samples were brought to room temperature prior the measurement.

\section{Does the addition of $\mathrm{H}_{2} \mathrm{O}_{2}$ cause a decrease in $\mathrm{pH}$ ?}

To better understand the effects that $\mathrm{H}_{2} \mathrm{O}_{2}$ may have on this system, CTec3 was incubated with pretreated wheat straw with and without four additions of $1 \mathrm{mg} \mathrm{H}_{2} \mathrm{O}_{2} / \mathrm{g}$ slurry, i.e., approximately $29 \mathrm{mM} \mathrm{H}_{2} \mathrm{O}_{2}$. The first dose of $\mathrm{H}_{2} \mathrm{O}_{2}$ was added after $18 \mathrm{~h}$ of pre-incubation to liquefy the lignocellulosic material. In the absence of catalase, the addition of $\mathrm{H}_{2} \mathrm{O}_{2}$ increased the amount of $\mathrm{KOH}$ required from 135 to $230 \mu \mathrm{L}$ during $120 \mathrm{~h}$ of incubation (data not shown). This is equivalent to a $60 \%$ increase in $\mathrm{KOH}$ requirement. An initial addition of $0.08 \mathrm{mg} / \mathrm{g}$ DM catalase to the reaction prevented the acidification caused by $\mathrm{H}_{2} \mathrm{O}_{2}$ addition, as evidenced by a titrant requirement of $135 \mu \mathrm{L}$ (data not shown). As reported previously [9], the glucose yield was reduced by the addition of $\mathrm{H}_{2} \mathrm{O}_{2}$ in a concentration-dependent manner, and the effect was more pronounced under reduced-oxygen conditions. A similar $\mathrm{H}_{2} \mathrm{O}_{2}$-dose-dependent decrease in $\mathrm{pH}$ after $24 \mathrm{~h}$ of incubation was seen in the absence of enzymes (Fig. 3c). It is, therefore, likely that $\mathrm{H}_{2} \mathrm{O}_{2}$ is involved in the oxidative acidification of the slurry.

\section{Does enzymatic $\mathrm{H}_{2} \mathrm{O}_{2}$ generation cause a decrease in $\mathrm{pH}$ and glucose yields?}

The effects of in situ-generated $\mathrm{H}_{2} \mathrm{O}_{2}$ on biomass acidification and glucose yields were then investigated by incubating CTec3 with steam-pretreated wheat straw in the presence and absence of MnAOx. These experiments were carried out under both ambient air and reducedoxygen conditions and in the presence and the absence of exogenous catalase. Graphs of cellulose conversion to glucose and gluconic acid under each of these conditions are shown in Fig. 4. These data were analysed using the kinetic models described in Additional file 2: Figures S2 and S3, to help evaluate the combined effects of MnAOx, oxygen, and catalase on glucose and gluconic acid production.

The addition of catalase to $\mathrm{CTec} 3$ increased glucose yields after $24 \mathrm{~h}$ of incubation in ambient air (Fig. 4a). Model fits to these progress curves suggest that catalase decreased the inactivation rate constant of CTec3, thereby increasing the half-life of the enzyme cocktail
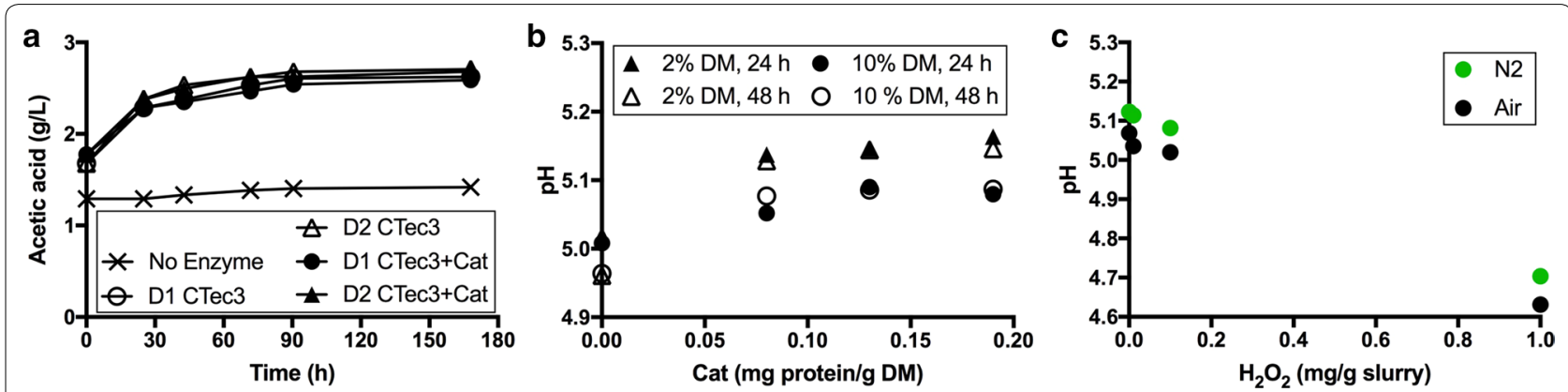

Fig. 3 Acetic acid release and $\mathrm{pH}$ in steam-pretreated wheat straw slurry adjusted to $\mathrm{pH} 5.3$ during incubation at $50^{\circ} \mathrm{C}$. a Acetic acid released during the saccharification of 10\% DM wheat straw slurry. The CTec3 loading was 2.8 (D1) or 8.4 (D2) mg total protein/g cellulose. The catalase loading was $0.08 \mathrm{mg}$ protein/g DM (approximately $11,000 \mathrm{U} / \mathrm{ml}$ slurry). b Addition of catalase reduces the decrease in pH during 24 and $48 \mathrm{~h}$ incubation of $2 \% \mathrm{DM}$, and $10 \%$ DM incubated for 24 and $48 \mathrm{~h}$. c Effect of added $\mathrm{H}_{2} \mathrm{O}_{2}$ (to a concentration of 2.9 and $29 \mathrm{mM}$ ) on the pH of $10 \% \mathrm{DM}$ wheat straw slurry after $24 \mathrm{~h}$ incubation at $50{ }^{\circ} \mathrm{C}$ under ambient air and reduced-oxygen conditions. The values given are the average of duplicate samples, and the error bars represent the standard deviation. Cat catalase, CTec3 Cellic CTec3 

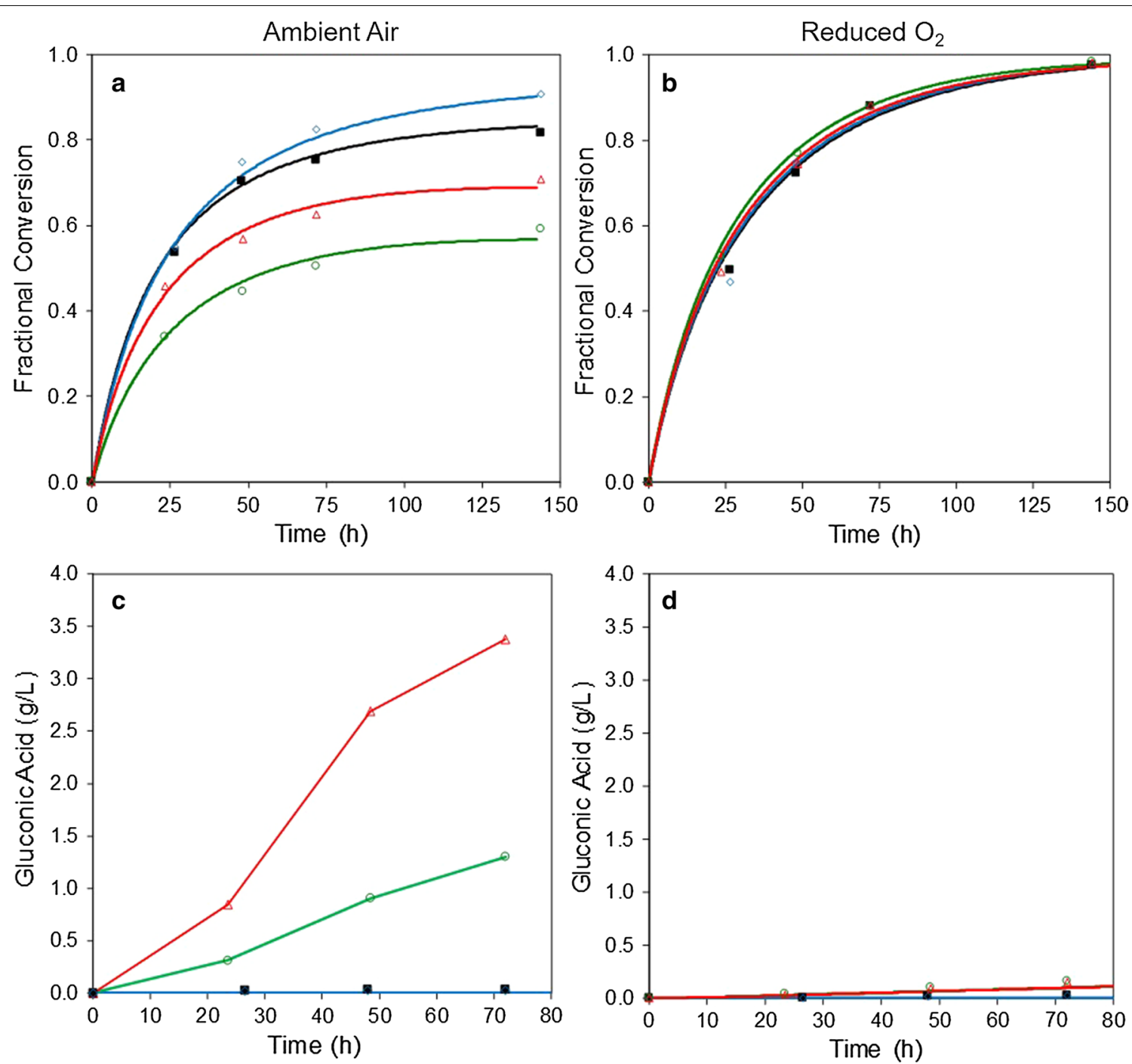

Fig. 4 Effect of catalase on cellulose hydrolysis in the presence and absence of MnAOx and reduced oxygen. Pretreated wheat straw was incubated at $50^{\circ} \mathrm{C}, \mathrm{pH} 5$ for $96 \mathrm{~h}$ under conditions of ambient air (approximately $20 \% \mathrm{O}_{2}$ ) or reduced oxygen (approximately $0.3 \% \mathrm{O}_{2}$ ). The enzyme cocktail consisted of CTec3 ( $8.4 \mathrm{mg}$ protein/g cellulose) and $0.22 \mathrm{mg} / \mathrm{g}$ cellulose catalase (blue diamonds), CTec3 + 0.22 mg/g cellulose MnAOx+ catalase (red triangles), CTec3 + MnAOx (green circles), or CTec3 alone (black squares). $\mathbf{a}$, b Show the fractional conversion of cellulose to glucose, while $\mathbf{c}$, $\mathbf{d}$ Show the concentrations of gluconic acid. The curves shown in $\mathbf{a}, \mathbf{b}$ are model fits

from 36 to $76 \mathrm{~h}$ (Table 2). The addition of catalase had no significant effect on the catalytic rate constant of CTec3. Both these observations are consistent with those in a previous study [9]. An overlay of these progress curves with those published previously is shown in Additional file 2: Figure S4.

The addition of MnAOx decreased the extent of cellulose conversion to glucose in ambient air within the first $24 \mathrm{~h}$ (Fig. 4a). The formation of gluconic acid accounted for a relatively small fraction of the total glucose equivalents produced (Fig. 4c). This suggests that MnAOx reduced cellulose conversion to glucose via a detrimental effect on CTec3 or on the pretreated wheat straw, rather than solely by producing oxidized glucose equivalents as alternative reaction products. This effect occurred early in the incubation and is reflected in the kinetic model as a decrease in the catalytic rate constant of $\mathrm{CTec} 3$ from 15.4 to $6.3 \mathrm{~g} \mathrm{~h}^{-1} \mathrm{~g}^{-1}$ (Table 2), while the inactivation rate constant remained constant. The combined addition of catalase and MnAOx markedly improved the conversion of cellulose to glucose when compared to the addition of MnAOx alone. Interestingly, gluconic acid concentrations also increased approximately threefold (Fig. 4c). When considering glucose and gluconic acid levels 
Table 2 Estimated values of the catalytic $\left(\boldsymbol{k}_{\mathrm{s}}\right)$ and inactivation $\left(k_{i}^{\mathrm{a}}\right)$ rate constants for CTec3 in the presence and the absence of MnAOx and catalase

\begin{tabular}{|c|c|c|c|c|}
\hline & $k_{\mathrm{s}}\left(\mathrm{gh}^{-1} \mathrm{~g}^{-1}\right)$ & $\begin{array}{l}k_{\mathrm{i}}^{\mathrm{a}}\left(10^{-2}\right. \\
\left.\mathrm{g} \mathrm{h}^{-1} \mathrm{~g}^{-1}\right)\end{array}$ & $t_{1 / 2}(\mathrm{~h})$ & $2 \mathrm{M} \mathrm{KOH}(\mu \mathrm{L})$ \\
\hline \multicolumn{5}{|l|}{ Ambient air } \\
\hline Control & $15.4 \pm 1.6$ & $1.95 \pm 0.4$ & $36 \pm 7$ & $120 \pm 0$ \\
\hline Cat & $14.5 \pm 1.5$ & $0.91 \pm 0.3$ & $76 \pm 27$ & $130 \pm 0$ \\
\hline MnAOx & $6.3 \pm 1.9^{*}$ & $1.67 \pm 0.8$ & $42 \pm 20$ & $400 \pm 28$ \\
\hline $\mathrm{Cat}+\mathrm{MnAO} x$ & $11.7 \pm 4.4$ & $1.60 \pm 0.6$ & $43 \pm 17$ & $473 \pm 4$ \\
\hline \multicolumn{5}{|l|}{ Reduced-oxygen } \\
\hline Control & $11.6 \pm 1.6$ & $n / a^{* *}$ & - & $100 \pm 0$ \\
\hline Cat & $11.3 \pm 1.7$ & $\mathrm{n} / \mathrm{a}^{* *}$ & - & $100 \pm 0$ \\
\hline MnAOx & $13.5 \pm 2.2$ & $\mathrm{n} / \mathrm{a}^{* *}$ & - & $110 \pm 0$ \\
\hline Cat $+\mathrm{MnAOx}$ & $12.5 \pm 1.4$ & $\mathrm{n} / \mathrm{a}^{* *}$ & - & $110 \pm 0$ \\
\hline
\end{tabular}

The $\mathrm{CTec} 3$ cellulose hydrolysis progress curves shown in Fig. $4 \mathrm{a}$, b were fit using the model shown in Additional file 2: Figure S2. The values estimated for $k_{\mathrm{s}}$ and $k_{i}^{\mathrm{a}}$ are shown below. Moreover, the amount of $2 \mathrm{M} \mathrm{KOH}$ required to adjust the $\mathrm{pH}$ to 5.0 is shown

* $P$ value $<0.05$ versus $C$ Tec 3 control under ambient air

** Estimated parameter value is indistinguishable from zero

together, cellulose conversion measured in the presence of catalase and MnAOx was similar to the CTec3-only control (Additional file 2: Figure S5).

The addition of catalase may have increased gluconic acid concentrations by stabilising $\mathrm{MnAO} x$ under these assay conditions. This is reasonable if the $\mathrm{H}_{2} \mathrm{O}_{2}$ produced as a co-product by $\mathrm{MnAO} x$ contributes to the oxidative inactivation of this enzyme as shown previously [25]. In degrading $\mathrm{H}_{2} \mathrm{O}_{2}$, catalase reduces the inactivation rate of $\mathrm{MnAO} x$. Alternatively, catalase may increase the apparent catalytic rate of MnAOx by producing oxygen in situ. If true, this would indicate that oxygen availability limits the activity of MnAOx in the absence of catalase, at least at some stages of the reaction. This is considered further in Additional file 2: Figure S6 and Table S4.

\section{Pronounced acidification of the slurry was observed in the presence of $\mathrm{MnAOx}$}

The $\mathrm{pH}$ of each saccharification reaction above was adjusted to 5.0 using a $2 \mathrm{M}$ solution of $\mathrm{KOH}$ at each sampling time and the total volume of $\mathrm{KOH}$ added is listed in Table 2. The total volume of $\mathrm{KOH}$ required to adjust the $\mathrm{pH}$ to 5.0 increased from $120 \mu \mathrm{L}$ in the absence of $\mathrm{MnAO} x$ to $400 \mu \mathrm{L}$ when it was added under the ambient air condition, while the glucose yield decreased. When catalase was included, in addition to $\mathrm{MnAO} x$, the volume of $\mathrm{KOH}$ increased further to $473 \mu \mathrm{L}$ and glucose yield increased. Therefore, as discussed above, the $\mathrm{KOH}$ requirement is not directly correlated to the glucose yield. The amount of titrant required is not a simple function of the concentration of gluconic acid produced, as can be seen when comparing the conditions with and without catalase. After $72 \mathrm{~h}$ of incubation in the presence of catalase, the molar titrant requirement relative to the molar production of gluconic acid was approximately $3: 1$, whereas it was approximately $6: 1$ in the absence of catalase. This provides further evidence that $\mathrm{H}_{2} \mathrm{O}_{2}$ contributes to acidifying reactions during the decomposition of lignocellulosic material.

\section{Pretreated wheat straw consumes oxygen}

The temperature-dependent rate of abiotic oxygen depletion in wheat straw slurry was determined in samples incubated without any stirring and with ambient air in the headspace using fluorescence-based sensors [26]. During incubation of the biomass at $50{ }^{\circ} \mathrm{C}$, the oxygen content decreased to $<0.5 \%$ oxygen saturation (Fig. $5 \mathrm{a}$ ). Here, $100 \%$ oxygen saturation means that the slurry is completely saturated with the air. A gradual acidification from $\mathrm{pH} 5.0$ to $\mathrm{pH} 4.8$ was observed by the end of each incubation cycle.

The change in oxygen saturation during incubation between 24 and $70{ }^{\circ} \mathrm{C}$ is well described as an exponential decay, with a linear correlation of the temperature and the oxygen half-life (Fig. 5b). For one experiment at $70{ }^{\circ} \mathrm{C}$, the headspace gas was not exchanged with fresh air between cycles, and the headspace oxygen content was also measured through three cycles of heating, each with drop of slurry DO, followed by cooling, measurement of headspace \%oxygen, mixing of biomass and headspace gas, and reheating. Starting at 95\%, headspace \%oxygen dropped to 74, 63 and $54 \%$ at the end of each cycle, while the slurry dropped to $<1 \%$ DO. Based on the change in oxygen content of the headspace, it is estimated that $18 \mu \mathrm{mol}$ oxygen was consumed during each cycle of incubation at $70{ }^{\circ} \mathrm{C}$ and $50 \mu \mathrm{mol} / \mathrm{g} \mathrm{DM} / 24 \mathrm{~h}$. This is a considerably larger number than the $4 \mu \mathrm{mol}$ oxygen expected to be soluble in the biomass at the start of incubation (Additional file 2: Table S4). Although the oxygen saturation in the biomass falls to $<0.5 \%$ during incubation, the oxygen content of the headspace remained high, demonstrating that the diffusion rate into the biomass from the headspace is lower than the rate of oxidation of biomass components.

\section{Decarboxylation reactions take place at industrially relevant saccharification conditions}

When running biomass saccharification experiments in stirred-tank reactors, it is common to observe the formation of air bubbles in the slurry (Additional file 1: Figure S2) during the incubation. To determine if the composition of the gases in the headspace of the reactor changes throughout the saccharification reaction, its chemical 


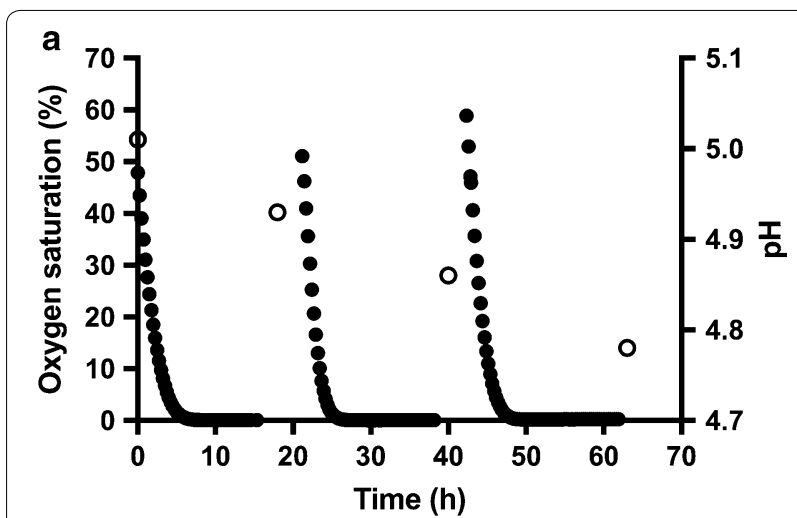

b

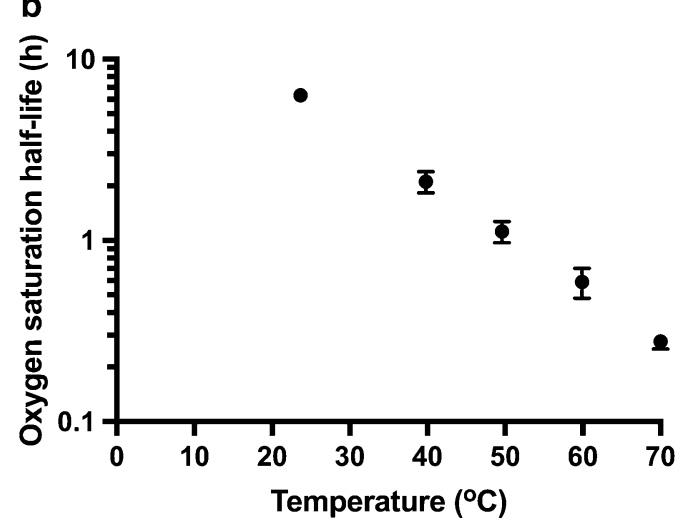

Fig. 5 a Oxygen saturation in pretreated wheat straw slurry during three rounds of incubation at $50^{\circ} \mathrm{C}$ (filled circles). The slurry was adjusted to $\mathrm{pH} 5.0$ prior to the initial incubation, and was noted after each round of incubation (empty circles). $\mathbf{b}$ Dependence of the half-life of the oxygen saturation on the temperature. Error bars show the standard deviation of the calculated half-live of oxygen for replicates at each temperature, with a singlet value at $23^{\circ} \mathrm{C}$

composition was determined using GC analysis. The gas pressure in the samples was also recorded in a parallel series of samples.

A considerable increase in the concentration of $\mathrm{CO}_{2}$ (up to $2.5 \%$ ) compared to ambient air $(0.0355 \%$ ) was immediately evident. From the results presented in Fig. 6, there is a positive correlation between temperature in the industrially relevant range of $40-60{ }^{\circ} \mathrm{C}$ and the concentration of $\mathrm{CO}_{2}$ in the headspace. The concentration of $\mathrm{CO}_{2}$ also increased with the DM content from 1 to $10 \%(\mathrm{wt} / \mathrm{wt})$, but the $\mathrm{CO}_{2}$ produced per gram of $\mathrm{DM}$ decreased.

The effect of enzymes on $\mathrm{CO}_{2}$ release was studied by the addition of cellulolytic enzyme cocktails, as described above. The $\mathrm{CO}_{2}$ produced during the first $24 \mathrm{~h}$ of incubation was about $9 \mu \mathrm{mol} / \mathrm{g} D \mathrm{DM}$ in the absence of enzymes, with inert protein (BSA) and with Celluclast ${ }^{\circledR}+$ BG. The addition of $\mathrm{CTec} 3$ reduced the $\mathrm{CO}_{2}$ concentration in the headspace compared with slurry alone and with BSA (Fig. 6d). However, the addition of catalase led to increased $\mathrm{CO}_{2}$ concentration in the headspace when added to the slurry in the absence of other enzymes. This effect is highly surprising in light of the $\mathrm{H}_{2} \mathrm{O}_{2}$-dependent $\mathrm{CO}_{2}$ production, as shown in Fig. $6 \mathrm{c}$ and discussed below. Catalase in combination with $\mathrm{CTec} 3$ also resulted in a higher $\mathrm{CO}_{2}$ concentration than $\mathrm{CTec} 3$ alone, and a value close to the $\mathrm{CO}_{2}$ produced in the slurry alone. Incubation for another $24 \mathrm{~h}$ resulted in similar relative concentrations of $\mathrm{CO}_{2}$ for the different conditions (Fig. 6e). The combination of Celluclast ${ }^{\circledR}$ and AA9 clearly resulted in the lowest $\mathrm{CO}_{2}$ concentration, while $\mathrm{CTec} 3$ alone and together with catalase gave more variable results, leading to large standard deviations.

\section{$\mathrm{H}_{2} \mathrm{O}_{2}$ addition leads to increased decarboxylation}

To determine whether $\mathrm{H}_{2} \mathrm{O}_{2}$ can be directly linked to $\mathrm{CO}_{2}$ production, we investigated whether the addition of three different amounts of $\mathrm{H}_{2} \mathrm{O}_{2}$ would change the $\mathrm{CO}_{2}$ profile of the gas in the headspace after $24 \mathrm{~h}$ of incubation at $50{ }^{\circ} \mathrm{C}$. The addition of $0.01 \mathrm{mg} \mathrm{H}_{2} \mathrm{O}_{2}$ /g slurry had no effect on $\mathrm{CO}_{2}$ production, whereas the addition of $0.1 \mathrm{mg} / \mathrm{g}$ slurry led to an approximate doubling of the $\mathrm{CO}_{2}$ production, compared to the slurry alone. The addition of $1.0 \mathrm{mg} \mathrm{H}_{2} \mathrm{O}_{2}$ /g slurry, i.e., $29 \mathrm{mM} \mathrm{H}_{2} \mathrm{O}_{2}$, led to a striking increase in the concentration, to $4 \mathrm{mM}$ ( $40 \mu \mathrm{mol} / \mathrm{g} \mathrm{DM}) \mathrm{CO}_{2}$, which is about 400 times the concentration in the air (Fig. 6c).

\section{Discussion}

The ubiquitous balancing act between the generation and elimination of reactive oxygen species is well known [27]. Tightly controlled coupling of oxygen consumption with hydrocarbon oxidation can be found in enzymes such as soluble methane monooxygenase, but is a major challenge in biocatalysis [28]. With the introduction of LPMOs in commercial cellulase cocktails, this is true also for industrial conversion of lignocellulose to ethanol [9]. Dissolved oxygen and electron donors with appropriate redox potential are required for LPMO activity. However, oxygen is unavoidably consumed by abiotic routes during degradation of organic matter [2]. In the present study, we found that such abiotic reactions in the saccharification slurry led to the acidification and decarboxylation of steam-pretreated wheat straw during incubation at industrially relevant conditions of $\mathrm{pH}$ and temperature. These chemical processes seem to be modulated by the presence of the oxido-reductases catalase and LPMO.

\section{Oxidative acidification}

It has been found that $2 \%$ dissolved oxygen saturation led to almost a doubling of the base titrant required to maintain the $\mathrm{pH}$ at 5.0 for the duration of enzymatic saccharification of pretreated wheat straw, compared 


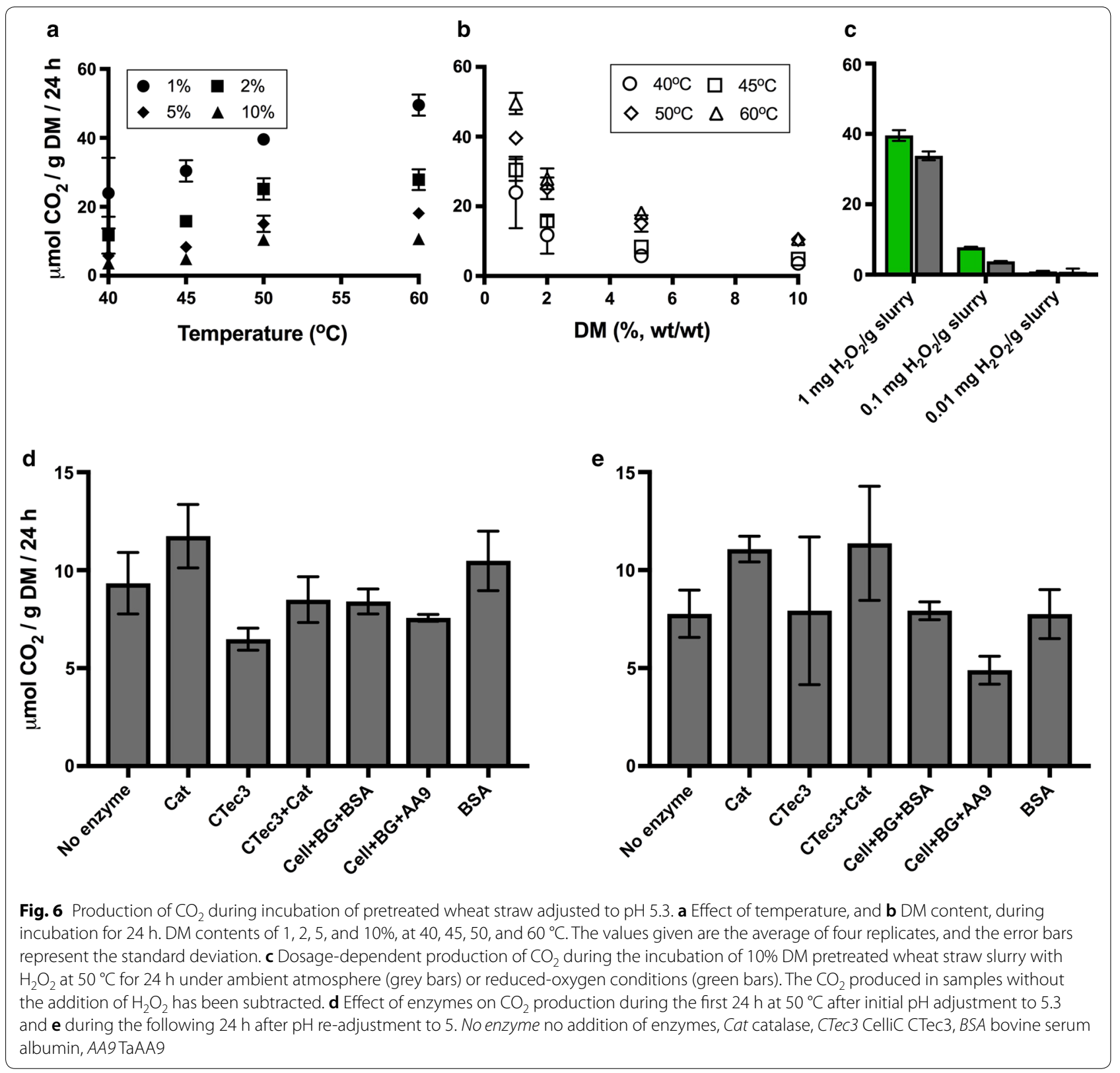

with the reduced-oxygen condition. It was also found that catalase could mitigate the titrant requirement (Table 1). The relationship between the oxidation and the acidification of decomposing plant material is seldom described in the biotechnological literature. We, therefore, investigated the effect of generic process parameters such as temperature and DM content on the acidification of steam-pretreated wheat straw.

\section{$\mathrm{H}_{2} \mathrm{O}_{2}$ addition increases acidification}

The mitigating effect of catalase on the requirement of base titrant was unexpected. The mechanism of catalase involves reduction by $\mathrm{H}_{2} \mathrm{O}_{2}$ of the active site $\mathrm{Fe}(\mathrm{III})$ of the enzyme. This is followed by proton/hydrogen abstraction and the release of water and oxygen, where both oxygen atoms originate from the same $\mathrm{H}_{2} \mathrm{O}_{2}$ molecule [29]. In other words, the catalase reaction per se is neutral, and does not explain the $\mathrm{pH}$-stabilising effect of catalase. It is possible that $\mathrm{H}_{2} \mathrm{O}_{2}$ is an intermediate in the acidifying reactions and that removal of $\mathrm{H}_{2} \mathrm{O}_{2}$ by catalase stabilised the $\mathrm{pH}$. Such a mechanism is supported by the observed decrease in $\mathrm{pH}$ due to both in situ-generated (Table 2) and exogenously added $\mathrm{H}_{2} \mathrm{O}_{2}$ (Fig. 3).

However, acidification by $\mathrm{H}_{2} \mathrm{O}_{2}$ has no straightforward chemical explanation. In acidic solutions, such as those encountered during the saccharification assays described 
here, $\mathrm{H}_{2} \mathrm{O}_{2}$ acts as a strong oxidizing agent, leading to the consumption of protons. In basic solutions, $\mathrm{H}_{2} \mathrm{O}_{2}$ is a reductant and protons are released. The reducing property of $\mathrm{H}_{2} \mathrm{O}_{2}$ in combination with lignocellulose has been observed previously by Banerjee et al. [30], who used alkaline $\mathrm{H}_{2} \mathrm{O}_{2}$ to pretreat corn stover and noted a downward shift in $\mathrm{pH}$. However, at $\mathrm{pH}$ values around $5, \mathrm{H}_{2} \mathrm{O}_{2}$ could be participating in chemical reactions with other compounds in the mixture, thereby indirectly causing the $\mathrm{pH}$ to fall.

\section{$\mathrm{H}_{2} \mathrm{O}_{2}$ effect on saccharification}

It was found that in situ $\mathrm{H}_{2} \mathrm{O}_{2}$ generation by aldose oxidase addition (under the conditions used) was detrimental to the saccharification process (Fig. 4a). The glucose concentration was reduced by about $1 / 3$ when the oxidase was present, and under these conditions, catalase can substantially, but not completely, alleviate this negative effect. The magnitude of the observed effect of $\mathrm{MnAO} x$ on glucose yields within the first $24 \mathrm{~h}$ is striking. This implies that one or more substrates for $\mathrm{MnAO} x$ are available early in the reaction, despite the relatively low cellulose conversion. Similarly, the low levels of gluconic acid suggest that substrates other than glucose or cellooligomers, such as cellobiose, are used. The specificity of $\mathrm{MnAO} x$ from $M$. nivale to different sugars, including xylose, has been reported [21, 31]. Using a Coprinus cinereus peroxidase-coupled assay based on the rate of $\mathrm{O}_{2}$ consumption, $\mathrm{Xu}$ et al. [21] determined that a recombinant MnAO $x$ had $K_{\mathrm{M}}$ of 42 and $59 \mathrm{mM}$, and $k_{\text {cat }}$ of 4 and $12 \mathrm{~s}^{-1}$, on glucose and cellobiose, respectively, at $40^{\circ} \mathrm{C}$. In addition, the relative activity of MnAOx on xylose (38\% of the activity on cellobiose) was only slightly lower than the activity reported on glucose (50\%). It is plausible that the high initial rate of MnAOx activity is due, at least in part, to the utilization of soluble sugars, including xylose and xylo-oligomers, from the pretreatment liquor.

It is unlikely that the oxidized glucose per se has a negative effect on the saccharification efficiency, as catalase improves the accumulation of both glucose and gluconic acid (Fig. 4c). The enzyme-stabilising effect of the removal of $\mathrm{H}_{2} \mathrm{O}_{2}$ by catalase, as discussed previously [ 9 , 25], is in agreement with this observation.

Recent findings propose that $\mathrm{H}_{2} \mathrm{O}_{2}$ can be a co-substrate (in place of dioxygen) in LPMO catalysis of polysaccharides cleavage in the presence of small amounts of reducing agent [11]. The kinetics of such reaction were studied by Kuusk et al. [12] and the molecular mechanism of such a reaction was studied by QM/MM calculations $[13,32]$. Due to the presence of endogenous reducing capacity in pretreated biomass, $\mathrm{H}_{2} \mathrm{O}_{2}$ could serve as a cosubstrate for the LPMO catalytic cycle on this material.
However, with the limited number of experimental conditions used in the present study, no evidence of a positive effect of added $\mathrm{H}_{2} \mathrm{O}_{2}$ is seen. What is clear is that $\mathrm{H}_{2} \mathrm{O}_{2}$ will react with lignocellulosic material to increase $\mathrm{H}^{+}$activity and produce $\mathrm{CO}_{2}$. Several publications discussing the relevance of $\mathrm{O}_{2}$ versus $\mathrm{H}_{2} \mathrm{O}_{2}$ as LPMO cosubstrate have appeared in the literature during the final stage of the review process of the current work [33-35], but no data for lignocellulosic material have been presented. The applicability of process configurations involving the addition of $\mathrm{H}_{2} \mathrm{O}_{2}$ for industrial saccharification of lignocellulose warrants still further investigation.

\section{Abiotic decarboxylation}

We observed an increase in $\mathrm{CO}_{2}$ concentration of up to 100 times in the headspace above slurry samples after $24 \mathrm{~h}$ of incubation at $50{ }^{\circ} \mathrm{C}$ (Fig. 6). To the best of our knowledge, decarboxylation reactions have not previously been discussed in the context of industrial enzymatic saccharification of lignocellulose. However, Miles and Brezonik [1] observed significant production of $\mathrm{CO}_{2}$ by oxygen-consuming reactions in natural humic-coloured waters. In these samples, the oxygen consumption increased with increasing DM content, with increasing $\mathrm{pH}$, and with the total concentration of iron in the sample.

Abiotic, oxygen-dependent $\mathrm{CO}_{2}$ release from pyrogallol in deionized distilled water has also been observed [36]. This process was increased by the addition of manganese, iron or aluminium oxides. $\mathrm{Fe}(\mathrm{III})$-containing mineral nontronite has also been found to increase $\mathrm{CO}_{2}$ release from the phenolic compounds pyrogallol, catechol, and hydroquinone [37]. The iron-oxide-catalysed reaction led to a final $\mathrm{pH}$ of 3.6 when the samples were incubated in the air and 4.2 under a nitrogen atmosphere; both of which were much lower than the initial $\mathrm{pH}$ of 6 of the experiment. The pretreated wheat straw used in the present study contained approximately $200 \mathrm{mg}$ iron $/ \mathrm{kg}$ of washed solids. It is likely that this content of iron (and other transition metals) in the material contributes to the abiotic acidifying and decarboxylating reactions.

\section{Abiotic drivers of decarboxylation}

This study was carried out on the lignocellulosic substrate steam-pretreated wheat straw. As a result of the release of organic acids during hydrothermal treatment, the material had a $\mathrm{pH}$ of 3.5-3.9 before adjustment of the DM content and $\mathrm{pH}$ of the slurry [38]. When temperature and $\mathrm{pH}$ was increased to moderate values used in the present study, significant abiotic reactivity of the pretreated material was evident by rapid consumption of oxygen (Fig. 5). It has been shown that $\mathrm{pH}$ scales linearly 
with the logarithm of the oxygen consumption in humic water samples [1], which substantiates our observation. The difference in $\mathrm{H}^{+}$activity is 25 -fold between $\mathrm{pH} 3.9$ (stock biomass) and 5.3 (saccharification conditions), and this will certainly change the equilibrium of the chemical reactions taking place in the slurry at the start of incubation.

The addition of $\mathrm{H}_{2} \mathrm{O}_{2}$ to the slurry under both ambient and reduced-oxygen conditions resulted in a dosagedependent reduction in $\mathrm{pH}$ (Fig. 3c) and concomitant production of $\mathrm{CO}_{2}$ (Fig. 6c). Ruff degradation of aldonic acids yielding aldoses with one less carbon atom and $\mathrm{CO}_{2}$ [39] is a possible explanation of this observation. However, in the absence of other enzymes, catalase reduces the decrease in the $\mathrm{pH}$ of the slurry during incubation while increasing the $\mathrm{CO}_{2}$ production. Ruff degradation driven by abiotic peroxide is, therefore, not sufficient to explain the oxidative acidification and decarboxylation of pretreated wheat straw during incubation at $50{ }^{\circ} \mathrm{C}$.

\section{Enzymatic contribution to decarboxylation}

Catalase enhances $\mathrm{CO}_{2}$ production, even in the absence of other enzymes (Fig. $6 \mathrm{~d}$, e). One possible explanation of the enhancing effect of catalase on $\mathrm{CO}_{2}$ production is that it is linked to the relatively slow phenol oxidase activity of the catalase itself [40]. Phenol oxidase activity on lignin-derived compounds may lead to a quinone intermediate that is prone to decarboxylation, as this has been reported for tyrosinase-catalysed decarboxylation of 3,4-dihydroxymandelate [41]. Oxidized and reduced quinones have been found ubiquitously in dissolved organic matter in environmental samples [42]. Oxidative decarboxylation of lignin-related benzoic acids by Aspergillus flavus [43] and by Pycnoporus cinnabarinus [44] has also been reported.

However, it should be noted that both catalase and $\mathrm{H}_{2} \mathrm{O}_{2}$ separately increased $\mathrm{CO}_{2}$ production (Fig. 6c, d), while the effect was to increase (Fig. 3b) and decrease $\mathrm{pH}$ (Fig. 3b, c), respectively. In contrast to catalase, LPMO reduced the $\mathrm{CO}_{2}$ production (Fig. $6 \mathrm{~d}$, e). We can thus exclude the decarboxylation of carboxylic acids by LPMO as the source of $\mathrm{CO}_{2}$ in the incubated samples. Such a reaction is catalysed by lactate oxidase, which is a flavincontaining monooxygenase [45]. Perhaps, the extent of decarboxylation leading to increased $\mathrm{CO}_{2}$ in this system is related to the availability of dissolved oxygen. Catalase and $\mathrm{H}_{2} \mathrm{O}_{2}$ addition both have the common effect of generating oxygen in situ via either the enzyme-mediated or spontaneous conversion of $\mathrm{H}_{2} \mathrm{O}_{2}$ to dioxygen and water. Similarly, LPMOs utilize dioxygen as a co-substrate and will have the effect of reducing dissolved oxygen concentrations.
Taken together, and illustrated in Fig. 7, these observations suggest that the redox enzymes redirect the electron flow in the lignocellulosic slurry.

\section{$\mathrm{CO}_{2}$ release affects $\mathrm{pH}$}

An increase in $\mathrm{CO}_{2}$ concentration of up to 100 -fold in the lignocellulosic slurry has a strong effect on $\mathrm{pH}$. For example, a rough calculation shows that $2 \% \mathrm{CO}_{2}$ in pure water has a $\mathrm{pH}$ of 4.4. The $\mathrm{pH}$ range in the pretreated biomass slurry was similar to the $\mathrm{pH}$ of some humic-rich water samples [1] and to the $\mathrm{pH}$ in the surface layers of Sphagnum peat bogs [46]. Peat bogs are characterised by surface layers that are hydrologically isolated from the influence of groundwater and surface water and from mineral matter in the sediments. Analysis of bog pore water samples has revealed that dissolved $\mathrm{CO}_{2}$ strongly influenced the $\mathrm{pH}$ of samples, where the partial pressure of $\mathrm{CO}_{2}$ was not in equilibrium with the atmosphere. For example, a water sample taken at a depth of $2 \mathrm{~m}$ had a $\mathrm{pH}$ of 5 , but after sparging the sample with $\mathrm{N}_{2}$ gas, the $\mathrm{pH}$ increased to 7.5. In such samples, organic acids and

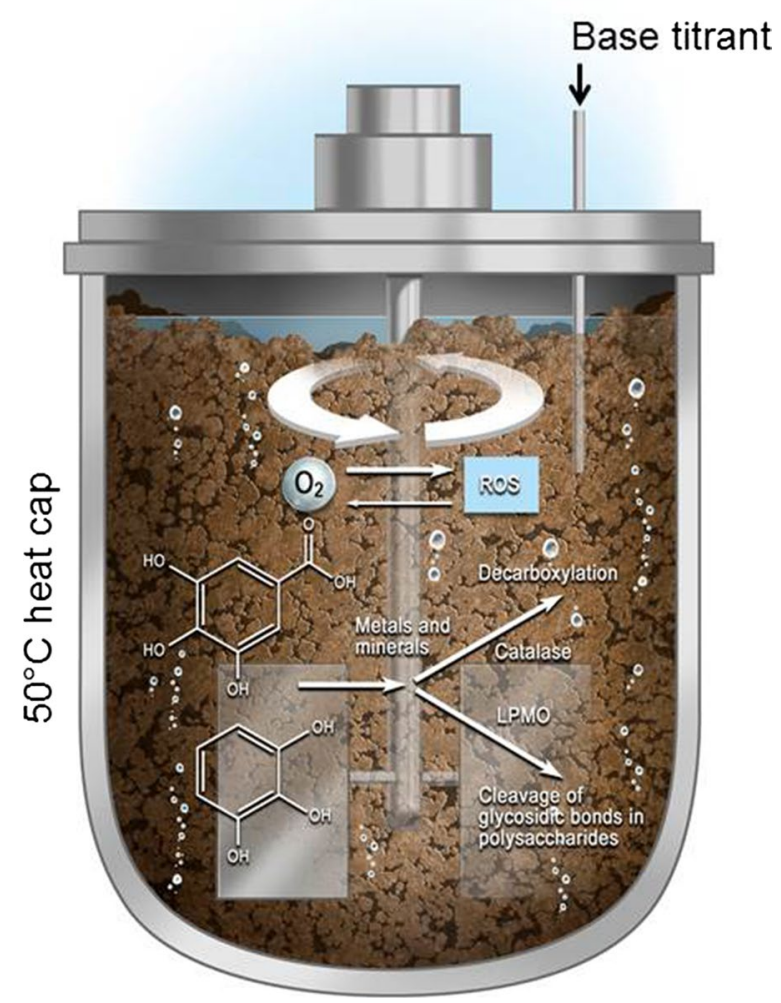

Fig. 7 Illustration of potential reaction paths for the critical redox processes during decomposition of lignocellulosic biomass. Protic electron-donating compounds present in the material, such as gallate and pyrogallol, contribute to both abiotic and enzymatic reactions 
dissolved $\mathrm{CO}_{2}$ are equally important acids in determining the $\mathrm{pH}$ [47]. The situation arising during industrial saccharification of lignocellulose thus appears to resemble that in a peat bog. Our preliminary results suggest that the principles discussed here for steam-pretreated wheat straw are general and apply to other lignocellulosic materials including wood.

In bio-industrial settings, the control of $\mathrm{pH}$ is critical and most commercial cellulases, including CTec3 used in this study, have a $\mathrm{pH}$ optimum around 5 .

We observed a more pronounced catalase-related reduction in titrant consumption in stirred-tank reactors set up with a constant air (gas) flow, than in assays using sealed tubes or vials. Catalase addition combined with the removal of $\mathrm{CO}_{2}$ by air exchange could be helpful in minimizing the need for base titrant while maintaining a certain level of dissolved oxygen during incubation. If the amount of $\mathrm{NaOH}$ consumed in $2 \mathrm{~L}$ stirred-tank reactors is extrapolated to a full-scale lignocellulosic ethanol factory (Additional file 1: Table S2), it is clear that the daily requirement of dry $\mathrm{NaOH}$ amounts to several tons. The significance of reducing this is evident, both in terms of economy and in terms of logistics. Moreover, the addition of $\mathrm{NaOH}$ will result in the formation of a range of salts, such as $\mathrm{NaCl}$ and $\mathrm{Na}_{2} \mathrm{CO}_{3}$, which require proper disposal. It is, therefore, of great importance in industry to limit the acidification of the lignocellulosic slurry as much as possible, even when such reactions do not directly lower the monosaccharide yield.

\section{Conclusions}

Controlled oxygen saturation in the reaction slurry is necessary during enzymatic saccharification of pretreated lignocellulose in industrial processes. A consequence of the oxic condition is abiotic reactions that lead to the acidification and decarboxylation of the lignocellulosic material. Addition of $\mathrm{H}_{2} \mathrm{O}_{2}$ as direct or indirect co-substrate of LPMOs gives similar effects. It will be important to control these processes in industrial settings.

As illustrated in Fig. 7, the redox enzymes change the course of such abiotic chemical reactions in the slurry. Most importantly, catalase stabilises the $\mathrm{pH}$ through a mechanism that could involve phenol oxidase activity of the enzyme or micro-oxygenation of the slurry. The result is likely to be increased decarboxylation of aromatic acids. Removal of $\mathrm{CO}_{2}$ by exchanging the headspace air may result in a more stable $\mathrm{pH}$ of the reaction slurry.

These observations may also be relevant for the decomposition of plant material in the environment as a reminder that $\mathrm{CO}_{2}$ production is not exclusively via respiration.

\section{Methods}

\section{Substrates, enzymes, and reagents}

All reagents were laboratory grade, unless otherwise stated. Two batches of steam-pretreated wheat straw slurry (kindly prepared by Mats Galbe, Lund University, Sweden) were used in the experiments (Additional file 2: Tables S1 and S2). The slurry (denoted SS-201400041) was the same as that used previously [9], and was received frozen, stored at $-20^{\circ} \mathrm{C}$, and thawed prior use. The solid composition of the insoluble pretreated solid fraction and the soluble pretreatment liquor are shown in Additional file 2: Tables S1 and S2. This material was used as whole slurry in all the experiments except those involving carbon dioxide measurements. The slurry from another batch using the same pretreatment was used in the experiments to measure carbon dioxide, and was stored in darkness at $+4{ }^{\circ} \mathrm{C}$. The commercial enzyme products $\mathrm{Cellic}^{\circledR} \mathrm{CTec} 3$ and Celluclast ${ }^{\circledR} 1.5 \mathrm{~L}$ and the following experimental enzymes were obtained from Novozymes A/S. The aldose oxidase used in this study was cloned from Microdochium nivale (Genbank Accession BD103535) and expressed from Fusarium venenatum [21]. Cloning and expression of the Thermoascus aurantiacus (Ta) AA9 (Accession ABW56451) were performed as previously described [48]. Catalase from Thermoascus aurantiacus (Accession DD046677) was expressed in Aspergillus niger and purified as described previously [49]. The properties of this enzyme were in accordance with previously published data [50] e.i.a calculated molecular weight of $75 \mathrm{kDa}, K_{\mathrm{m}}$ was $48 \mathrm{mM}$, and $K_{\text {cat }}$ was $137,000 \mathrm{~s}^{-1}$ (absorbance at $240 \mathrm{~nm}, 10 \mathrm{mM} \mathrm{H}_{2} \mathrm{O}_{2}$ in $50 \mathrm{mM}$ phosphate buffer pH 7.0 at $30{ }^{\circ} \mathrm{C}$ and unites defined as amount of enzyme that decompose $1 \mu \mathrm{mol}$ $\mathrm{H}_{2} \mathrm{O}_{2} / \mathrm{min}$ ). The $\beta$-glucosidase from Aspergillus fumigatus (Accession EAL88289) was cloned and expressed from Aspergillus oryzae as described elsewhere [51]. All the experimental enzymes were more than $90 \%$ pure. Bovine serum albumin (BSA) (98\% Sigma-Aldrich) was used as an inert protein. Enzymes and BSA aliquots were stored at $-20{ }^{\circ} \mathrm{C}$ until used. Enzyme stock samples were prediluted with tap water prior to addition to the slurry samples. Tap water was also used for the dilution of wheat straw slurry. $\mathrm{H}_{2} \mathrm{O}_{2}$ solution ( $\geq 30 \%$, SigmaAldrich) was used in the indicated reactions.

The iron content of the pretreated wheat straw was determined by in-house inductively coupled plasma optical emission spectrometry (ICP-OES) analysis at Novozymes and found to be approximately $200 \mathrm{mg} / \mathrm{kg}$ solid and $30 \mathrm{mg} / \mathrm{kg}$ liquid.

\section{Lignocellulose incubation with and without enzymes}

During saccharification in the presence and the absence of MnAOx in ambient air and reduced-oxygen 
conditions, pretreated wheat straw was incubated with CTec3, loaded at $8.4 \mathrm{mg}$ total protein/g cellulose, and the addition of catalase $0.22 \mathrm{mg} / \mathrm{g}$ cellulose (approximately $11.000 \mathrm{U} / \mathrm{ml}$ ) as described previously [9] unless otherwise stated. MnAOx was also loaded at $0.22 \mathrm{mg} / \mathrm{g}$ cellulose. Please see Additional file 2 for further details regarding the kinetics. The initial concentration of total dry matter was $10 \% \mathrm{w} / \mathrm{w}$, resulting in an initial cellulose concentration of $4 \% \mathrm{w} / \mathrm{w}$. The initial combined concentration of xylose and xylo-oligomers in the liquid portion of the pretreated substrate was $19.6 \mathrm{~g} / \mathrm{L}$.

For carbon dioxide $\left(\mathrm{CO}_{2}\right)$ measurements, experiments were performed using $15 \mathrm{~g}$ reactions in $30 \mathrm{~mL}$ serum bottles capped with airtight butyl rubber caps (Rubber B. V., The Netherlands, part No.: 7395), and sealed with aluminium crimp caps (with a removable centre) prior to incubation. Mixing was performed on an orbital shaker at $180 \mathrm{rpm}$. The $\mathrm{pH}$ was initially adjusted to 5.3 with $1 \mathrm{M}$ $\mathrm{KOH}$. Four DM concentrations (wt/wt), and 1, 2, 5, and $10 \%$ were investigated at temperatures of $40,45,50$, and $60{ }^{\circ} \mathrm{C}$ for $24 \mathrm{~h}$ without the addition of enzymes under ambient air conditions. $\mathrm{H}_{2} \mathrm{O}_{2}$ (from $\geq 30 \%$ stock solution) was added to the slurry preparations at $10 \% \mathrm{DM}$ to give final loadings of $0.01,0.1$, and $1 \mathrm{mg}_{2} \mathrm{O}_{2}$ /g of slurry, and the bottles were then capped and incubated for $24 \mathrm{~h}$ at $50{ }^{\circ} \mathrm{C}$. The same experiments, with the addition of $\mathrm{H}_{2} \mathrm{O}_{2}$, were performed under reduced-oxygen conditions. Wheat straw slurry at $10 \% \mathrm{DM}$, and $\mathrm{pH} 5.3$, was flushed with $\mathrm{N}_{2}$ for 15 min prior to placing the substrate in a disposable Atmosbag (Sigma-Aldrich) flushed with $\mathrm{N}_{2}$. Inside the Atmosbag, the substrate was aliquoted to serum bottles, and $\mathrm{H}_{2} \mathrm{O}_{2}$ was added prior to sealing the bottles. All the reactions with enzymes were performed in ambient air conditions. The effect of enzymes was investigated on $10 \%$ DM slurry at $50{ }^{\circ} \mathrm{C}$, by loading enzyme blends according to protein mass, consisting of $80 \%$ Celluclast $^{\circledR} 1.5 \mathrm{~L}, 10 \%$ BG and 10\% AA9 (or $10 \%$ BSA instead of TaAA9), or $100 \%$ CTec3, as described previously [9]. The total protein dose in each experiment was $4.9 \mathrm{mg}$ protein (not including catalase)/g DM. Catalase was loaded at $0.08 \mathrm{mg} / \mathrm{g}$ DM. After $24 \mathrm{~h}$ incubation, gas was sampled from the headspace and the pressure was measured (as described below). The bottles were opened and the $\mathrm{pH}$ was re-adjusted to 5 when the $\mathrm{pH}$ fell below 5 . The serum bottles were then sealed and incubation continued for an additional $24 \mathrm{~h}$. Control reactions were performed with catalase loadings of $0.08,0.13$, and $0.19 \mathrm{mg}$ as enzyme active protein on 2 and $10 \% \mathrm{DM}$ slurry. The samples were incubated at $50{ }^{\circ} \mathrm{C}$ for $48 \mathrm{~h}$ and measurements were made in the same manner after $24 \mathrm{~h}$ as described above, except that the $\mathrm{pH}$ was not adjusted. During $\mathrm{pH}$ measurements, the samples were mixed and the bottles were kept open in ambient air for about $1 \mathrm{~h}$.

\section{$\mathrm{GC}$ analysis of $\mathrm{CO}_{2}$ in the headspace}

The gas samples collected from the headspace were incubated in serum bottles sealed with airtight butyl rubber caps. A stopcock was mounted on the syringe, and gas samples of $3.5-4.0 \mathrm{~mL}$ were collected, by piercing the septum of the cap with the needle. The stopcock was closed after sample withdrawal. Care was taken not to allow the samples to cool during gas collection. The syringe containing the gas sample was then left to cool for 2 min at room temperature. The plunger of the syringe was then depressed until resistance was felt, prior to injection into a two-channel gas chromatography (GC) instrument (490 Micro GC, Agilent Technologies Sweden $A B)$, which was equipped with a thermal conductivity detector. Channel 1 was equipped with a $10 \mathrm{~m}$-long Molsieve 5 column, and helium was used as the carrier gas (at a pressure of $5.44 \mathrm{~atm}$ ), allowing for the analysis of methane, $\mathrm{O}_{2}$, and nitrogen. Channel 2 was equipped with a $10 \mathrm{~m}$-long CP-PoraPLOT U column, argon was used as the carrier gas (5.44 atm), and was used for the analysis of $\mathrm{CO}_{2}$. This column also allows for the analysis of methane. A backflush time of $13 \mathrm{~s}$, an injector temperature of $110{ }^{\circ} \mathrm{C}$, and a column temperature of $80^{\circ} \mathrm{C}$ were applied. None of the headspace air samples contained hydrogen or methane at levels above the detection level of the GC equipment. The $\mathrm{CO}_{2}$ calibration curve was obtained using gas standards with mole fractions ( $\mathrm{vol} / \mathrm{vol}$ ) of 10 , 30 , and $100 \% \mathrm{CO}_{2}$ (all of purity over $99.99 \%$ ). The number of moles $(n)$ of gas in the samples was calculated according to the ideal gas law:

$$
n=\frac{P V}{R T} \text {. }
$$

The pressure $(P)$ in the headspace was measured using a digital manometer (GMH 3111) and a relative pressure sensor (MSD 2,5 BRE; Greisinger Electronic, Regenstauf, Germany). Pressure measurements were performed after incubation by piercing the septum of the butyl rubber cap of the serum bottles.

\section{Consumption of $\mathrm{O}_{2}$}

Steam-pretreated wheat straw was used as whole slurry in experiments to measure the oxygen use during incubation without mixing. Samples of biomass were adjusted to pH 5 and 10\% total solids (\%TS) prior to use. Percent dissolved oxygen (DO) of the biomass slurry was measured by sensors (optodes) mounted inside gas impermeable reaction tubes (Corex, USA $25 \mathrm{~mL}$ model 8445, $30.5 \mathrm{~mL}$ total volume), with fluorescent quantitation of oxygen by Fibox4 (Presens, Germany). pH was measured by Orion 8175BNWP probe on Accumet XL600 meter (Fisher Scientific, USA), with temperature compensation. 
$16 \mathrm{~g}$ of $10 \%$ total solid biomass whole slurry was placed in tubes and then gassed with the air until the DO was $>80 \%$ ( $100 \%$ is defined as saturated with the air). Tubes were sealed with gasketed caps and oxygen impermeable Saran Wrap (Asahi Kasei, Japan) and incubated in a water bath without mixing at setpoints of $20,40,50,60$, and $70{ }^{\circ} \mathrm{C}$. DO of the substrate slurry was measured at $15 \mathrm{~min}$ intervals until the slurry DO was minimal, usually $<0.5 \%$. The tubes were then placed in a room temperature circulating water bath until chilled to $<23{ }^{\circ} \mathrm{C}$. Tubes (except $70{ }^{\circ} \mathrm{C}$ experiment) were then opened, the slurry measured for $\mathrm{pH}$, the headspace gas replaced with fresh air, and the slurry mixed well to oxygenate the biomass until the slurry DO was $>80 \%$ as measured at $20-23{ }^{\circ} \mathrm{C}$. Then, the tubes were returned to the incubation temperature $\left(20-70{ }^{\circ} \mathrm{C}\right)$ for measurement of DO. This could be repeated at least four times without apparent change in oxygen use rates. The headspace DO was also measured for the samples incubated at $70{ }^{\circ} \mathrm{C}$, without exchanging the headspace with fresh air. DO measurements attained during aeration and $\mathrm{pH}$ procedures when temperatures were below setpoints were not graphed or fitted.

DO measurements corresponding to timepoints within $0.5^{\circ} \mathrm{C}$ of the temperature setpoints were fitted as to $N_{0}$ (initial oxygen \%), $\mathrm{C}$ the steady-state final DO, and $\lambda$ (the decay rate) in an exponential decay formula (F1) by minimizing total pairwise error using the Microsoft Excel add-in Solver with the GRG method. Reaction rates can be described by half-life $=\ln (2) / \lambda ; N(t)$ represents the predicted \%DO at time $t$ :

$$
N(t)=\left(N_{0}-C\right) \mathrm{e}^{-\lambda t}+C .
$$

\section{Determination of glucose, xylose, and acetic acid}

The saccharified samples were analysed using HPLC with a Rezex ROA-Organic Acid $\mathrm{H}+(8 \%)$ column with a $3 \mathrm{~mm}$ I.D. (Phenomenex Inc.) maintained at $80{ }^{\circ} \mathrm{C}$ with a Carbo$\mathrm{H} 4$ guard cartridge (Phenomenex Inc.) maintained at room temperature. As eluent, $5 \mathrm{mM} \mathrm{H}_{2} \mathrm{SO}_{4}$ was used at a flow rate of $0.8 \mathrm{~mL} / \mathrm{min}$ in isocratic mode. Analytes were detected with a refractive index detector.

\section{Additional files}

Additional file 1. Abiotic reactivity of steam pretreated wheat straw. Additional file 2. Substrate composition and kinetic modelling of the saccharification process.

\footnotetext{
Abbreviations

BG: $\beta$-glucosidase; BSA: bovine serum albumin; Cat: catalase; Cell: Celluclast ${ }^{\circledR}$ 1.5L; CTec3: Cellic ${ }^{\circledR}$ CTec3; DM: dry matter; GC: gas chromatography; HPLC: high-performance liquid chromatography; ICP-OES: inductively coupled plasma optical emission spectrometry; LPMO: lytic polysaccharide monooxygenase; $M n A O x$ : aldose oxidase from Microdochium nivale; $t_{1 / 2}$ : enzyme
}

performance half-life; TaAA9: LPMO from Thermoascus aurantiacus which belongs to auxiliary activity family 9; wt/wt: weight per weight.

\section{Authors' contributions}

AP, LS, RH, KCMF, and JF conducted the experiments. KSJ directed the research BRS analysed data and performed the kinetic modelling. $L \varnothing$ contributed MnAOx and catalase. BRS, KCMF, AP, LO, and KSJ wrote the manuscript. All authors contributed to the discussion of the data. All authors read and approved the final manuscript.

\section{Author details \\ ${ }^{1}$ Division of Industrial Biotechnology, Department of Biology and Biologi- cal Engineering, Chalmers University of Technology, Kemivägen 10, 412 96 Gothenburg, Sweden. ${ }^{2}$ Novozymes Inc., 1445 Drew Ave, Davis, CA 95618, USA. ${ }^{3}$ Novozymes North America, 77 Perry's Chapel Church Road, Franklinton, NC 27525, USA. ${ }^{4}$ Novozymes A/S, Krogshøjvej 36, 2880 Bagsværd, Denmark. ${ }^{5}$ Department of Geosciences and Natural Resource Management, Copenha- gen University, Rolighedsvej 23, 1958 Frederiksberg, Denmark.}

\section{Acknowledgements}

We would like to thank illustrator Henning Dalhoff for assistance with Figs. 1 and 7 .

\section{Competing interests}

The authors declare that they have no competing interests; however, KCMF, JF, $L \varnothing, R H$, and $B R S$ are employed by Novozymes A/S.

\section{Availability of data and materials}

Data sharing is not applicable as no large data sets were generated or analysed during the study.

\section{Consent for publication}

Not applicable.

\section{Declarations}

Not applicable.

\section{Ethics approval and consent to participate}

The research did not involve human subjects, human material, or human data.

\section{Funding}

This work was partially funded by the Swedish Energy Agency, Grant No. 41259-1 to LO and KSJ and supported by the Novo Nordisk Foundation, Grant NNF17SA0027704 to KSJ.

\section{Publisher's Note}

Springer Nature remains neutral with regard to jurisdictional claims in published maps and institutional affiliations.

Received: 1 February 2018 Accepted: 31 May 2018

Published online: 18 June 2018

\section{References}

1. Miles CJ, Brezonik PL. Oxygen consumption in humic-colored waters by a photochemical ferrous-ferric catalytic cycle. Environ Sci Technol. 1981;15(9):1089-95.

2. Remucal CK, Sedlak DL. The role of iron coordination in the production of reactive oxidants from ferrous iron oxidation by oxygen and hydrogen peroxide. Acs Sym Ser. 2011;1071:177-97.

3. Fimmen RL, Cory RM, Chin Y-P, Trouts TD, McKnight DM. Probing the oxidation-reduction properties of terrestrially and microbially derived dissolved organic matter. Geochim Cosmochim Acta. 2007;71(12):3003-15.

4. Johansen KS. Discovery and industrial applications of lytic polysaccharide mono-oxygenases. Biochem Soc Trans. 2016;44(1):143-9.

5. Vaaje-Kolstad G, Westereng B, Horn SJ, Liu ZL, Zhai H, Sorlie M, Eijsink VGH. An oxidative enzyme boosting the enzymatic conversion of recalcitrant polysaccharides. Science. 2010;330(6001):219-22. 
6. Quinlan RJ, Sweeney MD, Lo Leggio L, Otten H, Poulsen JCN, Johansen KS, Krogh KBRM, Jorgensen Cl, Tovborg M, Anthonsen A, et al. Insights into the oxidative degradation of cellulose by a copper metalloenzyme that exploits biomass components. Proc Natl Acad Sci USA. 2011;108(37):15079-84.

7. Eibinger M, Sattelkow J, Ganner T, Plank H, Nidetzky B. Single-molecule study of oxidative enzymatic deconstruction of cellulose. Nat Commun 2017;8:894.

8. Muller G, Varnai A, Johansen KS, Eijsink VGH, Horn SJ. Harnessing the potential of LPMO-containing cellulase cocktails poses new demands on processing conditions. Biotechnol Biofuels. 2015;8:187.

9. Scott BR, Huang HZ, Frickman J, Halvorsen R, Johansen KS. Catalase improves saccharification of lignocellulose by reducing lytic polysaccharide monooxygenase-associated enzyme inactivation. Biotechnol Lett. 2016;38(3):425-34.

10. Xu F, Sweeney M, Quinlan J, Johansen KS. Aqueous composition useful for degrading or converting a cellulosic material, producing a fermentation product, and fermenting a cellulosic material comprises a polypeptide having cellulolytic enhancing activity and an organic compound. In: Novozymes (Novo-C) 2012;WO2012021396-A2012021391.

11. Bissaro B, Rohr AK, Muller G, Chylenski P, Skaugen M, Forsberg Z, Horn SJ, Vaaje-Kolstad G, Eijsink VGH. Oxidative cleavage of polysaccharides by monocopper enzymes depends on H2O2. Nat Chem Biol. 2017;13(10):1123-8.

12. Kuusk S, Bissaro B, Kuusk P, Forsberg Z, Eijsink VGH, Sørlie M, Väljamäe P. Kinetics of $\mathrm{H}_{2} \mathrm{O}_{2}$-driven degradation of chitin by a bacterial lytic polysaccharide monooxygenase. J Biol Chem. 2018;293(2):523-31.

13. Wang BJ, Johnston EM, Li PF, Shaik S, Davies GJ, Walton PH, Rovira C. QM/ MM studies into the $\mathrm{H} 2 \mathrm{O}$ 2-dependent activity of lytic polysaccharide monooxygenases: evidence for the formation of a caged hydroxyl radical intermediate. ACS Catal. 2018:8(2):1346-51.

14. Harris PV, Welner D, McFarland K, Re E, Navarro Poulsen J-C, Brown K, Salbo R, Ding H, Vlasenko E, Merino S. Stimulation of lignocellulosic biomass hydrolysis by proteins of glycoside hydrolase family 61: structure and function of a large, enigmatic family. Biochemistry. 2010;49(15):3305-16.

15. Westereng B, Cannella D, Wittrup Agger J, Jørgensen $H$, Larsen Andersen $M$, Eijsink VGH, Felby C. Enzymatic cellulose oxidation is linked to lignin by long-range electron transfer. Sci Rep. 2015;5:18561.

16. Cannella D, Möllers KB, Frigaard N-U, Jensen PE, Bjerrum MJ, Johansen $\mathrm{KS}$, Felby C. Light-driven oxidation of polysaccharides by photosynthetic pigments and a metalloenzyme. Nat Commun. 2016;7:11134.

17. Kracher D, Scheiblbrandner S, Felice AKG, BresImayr E, Preims M, Ludwicka K, Haltrich D, Eijsink VGH, Ludwig R. Extracellular electron transfer systems fuel cellulose oxidative degradation. Science. 2016;352(6289):1098-101.

18. Frommhagen M, Mutte SK, Westphal AH, Koetsier MJ, Hinz SWA, Visser J, Vincken J-P, Weijers D, van Berkel WJH, Gruppen H, et al. Boosting LPMOdriven lignocellulose degradation by polyphenol oxidase-activated lignin building blocks. Biotechnol Biofuels. 2017;10:121.

19. Frickman J, Liu J, Johansen KS, Huang HZ, Xu H. Saccharifying a cellulosic material comprises subjecting the cellulosic material to a cellulolytic enzyme composition, a glycoside hydrolase Family 61 polypeptide, and a catalase in a vessel. In: Novozymes (Novo-C): WO2015066492-A2015066491.

20. Horn SJ, Eijsink VGH. Enzymatic hydrolysis of steam-exploded hardwood using short processing times. Biosci Biotech Biochem. 2010;74(6):1157-63.

21. Xu F, Golightly EJ, Fuglsang CC, Schneider P, Duke KR, Lam L, Christensen $\mathrm{S}$, Brown KM, Jorgensen CT, Brown SH. A novel carbohydrate:acceptor oxidoreductase from Microdochium nivale. Eur J Biochem. 2001;268(4):1136-42.

22. Dizhbite T, Telysheva G, Jurkjane V, Viesturs U. Characterization of the radical scavenging activity of lignins - natural antioxidants. Bioresour Technol. 2004;95(3):309-17.

23. Morelli R, Russo-Volpe S, Bruno N, Lo Scalzo R. Fenton-dependent damage to carbohydrates: free radical scavenging activity of some simple sugars. J Agric Food Chem. 2003;51(25):7418-25.
24. Hernandez-Marin E, Martinez A. Carbohydrates and their free radical scavenging capability: a theoretical study. J Phys Chem B. 2012:116(32):9668-75.

25. Nordkvist M, Nielsen PM, Villadsen J. Oxidation of lactose to lactobionic acid by a Microdochium nivale carbohydrate oxidase: kinetics and operational stability. Biotechnol Bioeng. 2007;97(4):694-707.

26. Di Russo NV, Bruner SD, Roitberg AE. Applicability of fluorescence-based sensors to the determination of kinetic parameters for $\mathrm{O}_{2}$ in oxygenases. Anal Biochem. 2015:475:53-5.

27. Rodriguez R, Redman R. Balancing the generation and elimination of reactive oxygen species. Proc Natl Acad Sci USA. 2005;102(9):3175-6.

28. Wang WX, Liang AD, Lippard SJ. Coupling oxygen consumption with hydrocarbon oxidation in bacterial multicomponent monooxygenases. Acc Chem Res. 2015;48(9):2632-9.

29. Alfonso-Prieto M, Biarnes X, Vidossich P, Rovira C. The molecular mechanism of the catalase reaction. J Am Chem Soc. 2009;131(33):11751-61.

30. Banerjee G, Car S, Scott-Craig JS, Hodge DB, Walton JD. Alkaline peroxide pretreatment of corn stover: effects of biomass, peroxide, and enzyme loading and composition on yields of glucose and xylose. Biotechnol Biofuels. 2011:4:16.

31. Baumann MJ, Murphy L, Lei NN, Krogh KBRM, Borch K, Westh P. Advantages of isothermal titration calorimetry for xylanase kinetics in comparison to chemical-reducing-end assays. Anal Biochem. 2011;410(1):19-26.

32. Hedegard ED, Ryde U. Molecular mechanism of lytic polysaccharide monooxygenases. Chem Sci. 2018;9(15):3866-80.

33. Hangasky JA, lavarone AT, Marletta MA. Reactivity of $\mathrm{O}_{2}$ versus $\mathrm{H}_{2} \mathrm{O}_{2}$ with polysaccharide monooxygenases. Proc Natl Acad Sci USA. 2018;115(19):4915-20.

34. Hangasky JA, Marletta MA. A random-sequential kinetic mechanism for polysaccharide monooxygenases. Biochemistry. 2018. https://doi. org/10.1021/acs.biochem.8b00129.

35. Vu W, Ngo ST. Copper active site in polysaccharide monooxygenases. Coord Chem Rev. 2018:368:134-57.

36. Wang MC, Huang PM. Ring cleavage and oxidative transformation of pyrogallol catalyzed by $\mathrm{Mn}, \mathrm{Fe}, \mathrm{Al}$, and Si oxides. Soil Sci. 2000;165(12):934-42.

37. Huang PM, Hardie AG. Formation mechanisms of humic substances in the environment. In: Senesi N, Xing B, Huang PM, editors. Biophysicochemical processes involving natural nonliving organic matter in environmental systems. Wiley: Hoboken; 2009. p. 41-109.

38. Rissanen JV, Grenman H, Willfor S, Murzin DY, Salmi T. Spruce hemicellulose for chemicals using aqueous extraction: kinetics, mass transfer, and modeling. Ind Eng Chem Res. 2014;53(15):6341-50.

39. Stapley JA, BeMiller JN. The Ruff degradation: a review of previously proposed mechanisms with evidence that the reaction proceeds by a Hofer-Moest-type reaction. Carbohyd Res. 2007;342(3-4):407-18.

40. Kocabas DS, Bakir U, Phillips SEV, McPherson MJ, Ogel ZB. Purification, characterization, and identification of a novel bifunctional catalase-phenol oxidase from Scytalidium thermophilum. Appl Microbiol Biotechnol. 2008;79(3):407-15.

41. Sugumaran M. Tyrosinase catalyzes an unusual oxidative decarboxylation of 3,4-dihydroxymandelate. Biochemistry. 1986;25(16):4489-92.

42. Cory RM, McKnight DM. Fluorescence spectroscopy reveals ubiquitous presence of oxidized and reduced quinones in dissolved organic matter. Environ Sci Technol. 2005;39(21):8142-9.

43. Palazzolo MA, Mascotti ML, Lewkowicz ES, Kurina-Sanz M. Self-sufficient redox biotransformation of lignin-related benzoic acids with Aspergillus flavus. J Ind Microbiol Biot. 2015:42(12):1581-9.

44. Hatakka Al. Degradation of veratric acid and other lignin-related aromatic-compounds by the white-rot fungus Pycnoporus Cinnabarinus. Arch Microbiol. 1985;141(1):22-8.

45. Melzer E, Schmidt HL. Carbon isotope effects on the decarboxylation of carboxylic acids. Comparison of the lactate oxidase reaction and the degradation of pyruvate by $\mathrm{H}_{2} \mathrm{O}_{2}$. Biochem J. 1988;252(3):913-5.

46. Shotyk W. Review of the inorganic geochemistry of peats and peatland waters. Earth-Sci Rev. 1988:25(2):95-176.

47. Steinmann P, Shotyk W. Chemical composition, $\mathrm{pH}$, and redox state of sulfur and iron in complete vertical porewater profiles from two Sphagnum 
peat bogs, Jura Mountains, Switzerland. Geochim Cosmochim Acta. 1997;61(6):1143-63.

48. Dotson WD, Greenier J, Ding H. Polypeptides having cellulolytic enhancing activity and polynucleotides encoding same. 2007. US Patent: US 7,271,244, USPTO.

49. Haruhiko KKY, Sadaji U. Catalase gene. 2004. Japanese Patent: JP 2004-261137.
50. Wang H, Tokusige Y, Shinoyama H, Fujii T, Urakami T. Purification and characterization of a thermostable catalase from culture broth of Thermoascus aurantiacus. J Ferment Bioeng. 1998:85(2):169-73.

51. Teter SC, Ward C, Jones A, Harris P, Yi J. Variants of glycoside hydrolases. 2008. US Patent: US 8,383,385, USPTO
Ready to submit your research? Choose BMC and benefit from:

- fast, convenient online submission

- thorough peer review by experienced researchers in your field

- rapid publication on acceptance

- support for research data, including large and complex data types

- gold Open Access which fosters wider collaboration and increased citations

- maximum visibility for your research: over $100 \mathrm{M}$ website views per year

At BMC, research is always in progress.

Learn more biomedcentral.com/submissions 